\title{
Pengaruh Indeks Sinkronisasi dalam Rumen pada Ransum Berbasis Bagase terhadap Produksi VFA Rumen pada Domba
}

\section{Effects of Synchronization Index in the Sugarcane Bagasse Based Ration on the Volatile Fatty Acid Production of Sheep}

\author{
Novi Eka Wati \\ Fakultas Peternakan, Universitas Tulang Bawang Lampung. J I. Gajah Mada No.34 Kotabaru, \\ Bandar Lampung \\ novi.ekawati1990@utb.ac.id
}

\begin{abstract}
The aim of the research was to study the effects of synchronization index in the sugarcane bagasse based ration on acetate, propionate and butirate production of sheep. Two permanent cannulated male local sheep was 2 years old for sampling rumens fluids. They were feed a complete feed based on bagasse with a level of synchrony index 0,37 ; 0,$50 ; 0,63$ were design isoprotein and isoenergy. Each experimental diet was offered to each sheep three times randomly for 7 days, with 7 days interval between feeding period of each experimental diet. About $10 \mathrm{ml}$ of rumen fluid sample were collected before feeding and 3 hour after feeding at the 7th day of each feeding trial period. The alteration of synchronization indexs did not affect acetate, propionate, butirate and ratio acetate/propionate (C2/C3) in rumen before feeding and 3 hour after feeding.
\end{abstract}

Key words : acetate, butirat, propionate, synchrony index

\section{PENDAHULUAN}

Bagase adalah hasil samping tanaman tebu yang dapat dimanfaatkan sebagai sumber serat bagi ruminansia. Bagase potensial sebagai pengganti hijauan karena ketersediaannya melimpah, namun pemanfaatannya dalam ransum terbatas karena NDF yang tinggi sebesar $86,87 \%$ dan kandungan protein kasar yang rendah sebesar $1,45 \%$ (Sani et al., 2012). Penyusunan ransum bagi ternak ruminansia dilakukan berdasarkan kecukupan kebutuhan nutrien untuk mendukung sintesis protein mikrobia dalam rumen. Sintesis protein mikrobia sangat penting bagi ternak ruminansia karena sumber protein pada ruminansia lebih dari $60 \%$ dipenuhi oleh protein mikrobia dalam rumen. Kondisi yang ideal bagi sintesis protein mikrobia dalam rumen adalah prekusor nitrogen merupakan hasil degradasi protein di dalam rumen berupa $\mathrm{NH}_{3}$ dan dan karbon merupakan hasil degradasi karbohidrat berupa VFA. VFA (volatile fatty acid) berupa asam asetat $\left(\mathrm{C}_{2}\right)$, asam propionat $\left(\mathrm{C}_{3}\right)$ dan asam butirat $\left(\mathrm{C}_{4}\right)$ sebagai sumber energi bagi mikrobia dalam rumen (Rahmadi et al., 2010).

Sintesis protein mikrobia yang maksimal dapat dicapai dengan adanya sinkronisasi antara pasokan energi dan protein pakan berdasarkan tingkat degradabilitasnya di dalam 
rumen sehingga waktu pelepasan VFA dan $\mathrm{NH}_{3}$ yang sinkron dan jumlahnya mencukupi. Sinkronisasi antara pasokan energi dan protein dinyatakan dalam indeks sinkronisasi yang merupakan rasio antara $\mathrm{N}$ terdegradasi dengan $\mathrm{BO}$ terdegradasi di dalam rumen yang diukur secara in sacco. Nilai indeks sinkronisasi sebesar 1 menunjukkan sinkronisasi sempurna antara pasokan protein dan energi dalam satu satuan waktu, sehingga nilai indeks sinkronisasi dalam ransum semakin mendekati 1,0 mengindikasikan bahwa tingkat kesinkronan semakin tinggi (Hermon et al., 2008), (Sinclair et al., 1993). Nilai indeks sinkronisasi perlu dipertimbangkan dalam penyusunan ransum agar terjadi keseimbangan antara produksi VFA dan $\mathrm{NH}_{3}$ dalam rumen sehingga sintesis protein mikrobia dalam rumen maksimal dan ketersediaan asam amino bagi ternak meningkat. Tujuan penelitian adalah mengkaji pengaruh pemberian ransum berbasis bagase dengan sinkronisasi pasokan energi dan nitrogen dalam rumen terhadap produksi asetat, propionat dan butirat di dalam rumen serta rasio asam asetat/propionat.

\section{MATERI DAN METODE}

Materi yang digunakan dalam penelitian ini adalah dua ekor domba jantan berfistula berumur \pm 2 tahun. Pakan yang diberikan berupa ransum berbasis bagase yang disusun isoprotein dan iso energi dengan index sinkronisasi sebesar 0,37 (P1), 0,50 (P2) dan 0,63 (P3). Formulasi ransum perlakuan dan kandungan nutrien ransum perlakuan tersaji dalam Tabel 1.

Adaptasi pakan dan lingkungan dilakukan selama 4 minggu dan perlakuan pakan dilakukan selama 8 minggu. Setiap ransum perlakuan diberikan pada semua domba selama 7 hari secara acak. Domba dikandangkan dalam kandang metabolik individual dan diberi minum secara ad libitum terukur. Cairan rumen diambil dari fistula domba sebelum pemberian pakan dan 3 jam setelah pemberian pakan pada hari ke 7 perlakuan. Cairan rumen yang diambil dimasukkan kedalam botol dan ditambahkan $\mathrm{HgCl}_{2} \mathrm{H}_{3} \mathrm{PO}_{4}$ sebagai pengawet dengan perbandingan 1:10. Konsentrasi asetat, propionat dan butirat dianalisis dengan metode gas kromatografi (AOAC, 1995). Data dianalisis dengan ANOVA, jika terdapat pengaruh nyata dilanjutkan dengan uji DMRT untuk mengetahui perbedaan antar perlakuan (Steel and Torrie, 1981).

Tabel 1. Formulasi dan Kandungan Nutrien Ransum Perlakuan

\begin{tabular}{lccc}
\hline \multirow{2}{*}{ Komposisi Ransum } & \multicolumn{3}{c}{ Perlakuan Indeks Sinkronisasi } \\
\cline { 2 - 4 } Komponen Bahan & P1 & P2 & P3 \\
Bagase & 25,00 & 25,00 & 25,00 \\
Dedak & 2,50 & 4,00 & 5,60 \\
Tetes & 2,00 & 4,00 & 7,00 \\
Bungkil kelapa & 2,50 & 6,00 & 16,30
\end{tabular}




\begin{tabular}{|c|c|c|c|}
\hline Urea & 0,70 & 0,50 & 0,20 \\
\hline Bungkil Sawit & 16,50 & 9,00 & 1,00 \\
\hline Kulit kopi & 2,30 & 2,00 & 3,80 \\
\hline Onggok & 30,20 & 15,50 & 2,20 \\
\hline Pollard & 1,10 & 15,50 & 23,00 \\
\hline Kulit kacang & 1,60 & 3,50 & 3,60 \\
\hline Jagung & 5,80 & 4,50 & 0,50 \\
\hline Bungkil Kedelai & 11,30 & 10,00 & 11,30 \\
\hline \multicolumn{4}{|l|}{ Kandungan Nutrisi } \\
\hline bu & 4,36 & 4,97 & 5,87 \\
\hline 3ahan organik & 95,64 & 95,03 & 94,13 \\
\hline rotein kasar & 12,06 & 12,17 & 12,95 \\
\hline emak kasar & 3,37 & 3,44 & 3,70 \\
\hline Serat kasar & 25,30 & 24,60 & 25,32 \\
\hline BETN & 54,91 & 54,82 & 52,16 \\
\hline DN & 62,05 & 62,93 & 62,96 \\
\hline JDF & 54,80 & 55,97 & 55,98 \\
\hline ADF & 32,85 & 32,12 & 31,67 \\
\hline si sel & 45,20 & 44,03 & 44,02 \\
\hline Karbohidrat (KH) & 80,21 & 79,42 & 77,48 \\
\hline Karbohidrat non struktural (KH NS) & 25,41 & 23,45 & 21,50 \\
\hline Hemiselulosa & 21,95 & 23,84 & 24,31 \\
\hline
\end{tabular}

\section{HASIL DAN PEMBAHASAN}

Level indeks sinkronisasi ransum tidak memberikan pengaruh nyata $(P>0,05)$ terhadap produksi asam asetat, asam propionat dan asam butirat di dalam rumen domba pada 0 jam (sebelum pemberian pakan) maupun 3 jam setelah pemberian pakan. Prosuksi asam asetat, propionat, butirat dan rasio C2/C3 tersaji dalam tabel 2.

Tabel 2. Produksi Asam Asetat, Asam Propionat, Asam Butirat dan Rasio C2/C3

\begin{tabular}{|c|c|c|c|c|c|}
\hline \multirow{3}{*}{ Parameters } & \multirow{3}{*}{ Jam } & \multicolumn{3}{|c|}{ Diet } & \multirow{3}{*}{ Ket } \\
\hline & & P1 & P2 & P3 & \\
\hline & & \multicolumn{3}{|c|}{ 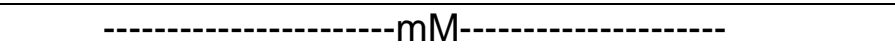 } & \\
\hline \multirow[t]{2}{*}{ Asam Asetat (C2) } & 0 & $26,13 \pm 0,32$ & $27,27 \pm 0,32$ & $26,43 \pm 0,32$ & ns \\
\hline & 3 & $44,77 \pm 2,69$ & $45,00 \pm 2,69$ & $47,33 \pm 2,69$ & ns \\
\hline \multirow[t]{2}{*}{ Asam Propionat (C3) } & 0 & $13,51 \pm 0,29$ & $14,72 \pm 0,29$ & $14,72 \pm 0,29$ & ns \\
\hline & 3 & $21,97 \pm 2,14$ & $23,41 \pm 2,14$ & $28,40 \pm 2,14$ & ns \\
\hline \multirow[t]{2}{*}{ Asam Butirat (C4) } & 0 & $7,28 \pm 0,20$ & $7,80 \pm 0,20$ & $7,64 \pm 0,20$ & ns \\
\hline & 3 & $4,16 \pm 0,34$ & $3,74 \pm 0,34$ & $3,97 \pm 0,34$ & ns \\
\hline \multirow[t]{2}{*}{ Rasio C2/C3 } & 0 & $1,93 \pm 0,05$ & $1,85 \pm 0,05$ & $1,87 \pm 0,05$ & ns \\
\hline & 3 & $2,06 \pm 0,13$ & $1,92 \pm 0,13$ & $1,71 \pm 0,13$ & ns \\
\hline
\end{tabular}

Keterangan: $\quad$ ns $=$ tidak berbeda nyata $(P>0,05)$

Nilai tersebut merupakan rata-rata dari 4 ulangan \pm sd 
Produksi asam asetat rumen domba sebelum pemberian ransum dan 3 jam setelah pemberian ransum perlakuan tidak berbeda nyata $(P>0,05)$ pada ransum $P 1, P 2$ dan $P 3$. Hal ini tidak sesuai dengan hasil penelitian Seo et al., (2010) bahwa level indeks sinkronisasi ransum sapi Holstein yang semakin tinggi menghasilkan konsentrasi asam asetat, propionat dan butirat yang semakin tinggi. Produksi asam asetat meningkat dari sebelum pemberian ransum hingga 3 jam setelah pemberian ransum. Peningkatan produksi asam asetat disebabkan adanya proses fermentasi serat yang terkandung di dalam ransum perlakuan.

Produksi asam propionat rumen domba sebelum pemberian ransum dan 3 jam setelah pemberian ransum perlakuan tidak berbeda nyata $(P>0,05)$ pada ransum $P 1, P 2$ dan P3. Produksi asam propionat meningkat dari sebelum pemberian ransum hingga 3 jam setelah pemberian ransum. Hal ini disebabkan adanya proses fermentasi karbohidrat di dalam rumen dan adanya pemecahan asam laktat dan didegradasi di dalam rumen menjadi asam propionat. Zamillah et al. (2011) menyatakan bahwa propionat akan diabsorbsi masuk dalam darah, menuju ke hati dan diubah menjadi glukosa darah sebagai sumber energi untuk ruminansia.

Produksi asam butirat rumen domba sebelum pemberian ransum dan 3 jam setelah pemberian ransum perlakuan tidak berbeda nyata $(P>0,05)$ pada ransum $P 1, P 2$ dan $P 3$. Produksi asam butirat rumen domba yang diberi ransum $\mathrm{P} 1, \mathrm{P} 2$ dan $\mathrm{P} 3$ cenderung menurun dari sebelum pemberian ransum hingga 3 jam setelah pemberian ransum. Hal ini disebabkan karena asam butirat memiliki sifat absorbsi oleh dinding rumen yang lebih cepat dibandingkan asam asetat dan propionat. Sesuai pendapat Pamungkas et al. (2008) bahwa propionat dan asetat mempunyai sifat absorbsi yang lebih lambat dibanding butirat yang memiliki jumlah yang sedikit. Richardson et al. (2003) menyatakan bahwa peningkatan level indeks sinkronisasi ransum menghasilkan konsentrasi asetat, propionat, butirat dalam rumen yang tidak signifikan.

Rasio C2/C3 rumen domba sebelum pemberian ransum dan 3 jam setelah pemberian ransum perlakuan tidak berbeda nyata $(P>0,05)$ pada domba yang diberi ransum P1, P2 dan P3. Rasio asetat dan propionat yang sama pada hasil penelitian diduga disebabkan oleh kandungan karbohidrat yang sama antar perlakuan. Arora (1995) menyatakan bahwa konsentrasi VFA rumen dipengaruhi oleh konsumsi karbohidrat yang terdiri dari serat dan BETN. Kandungan BETN ransum perlakuan P1, P2 dan P3 sama yaitu sebesar 54,91\%, 54,82\% dan 52,16\%. Besarnya kandungan NDF ransum P1, P2 dan P3 sama yaitu 54,80\%,55,97\% dan 55,98\%. Hal ini mengakibatkan besarnya konsentrasi asetat dan propionat pada 0 dan 3 jam setelah pemberian pakan tidak berbeda nyata sehingga rasio asetat dan propionat tidak berbeda nyata. Rasio C2/C3 pada rumen domba yang diberi ransum P1 dan P2 cenderung meningkat dari sebelum pemberian ransum hingga 3 jam setelah pemberian ransum perlakuan, sedangkan pada P3 cenderung menurun. Menurut pendapat Piao et al., (2012) dan Wati et al., (2015), peningkatan level 
indeks sinkronisasi ransum menghasilkan rasio asetat dan propionat dalam rumen dan glukosa darah yang tidak signifikan.

\section{KESIMPULAN}

Sinkronisasi suplai energi dan protein pakan dalam rumen tidak berpengaruh nyata terhadap produksi asam asetat, propionat dan butirat pada 0 jam dan 3 jam setelah pemberian pakan pada rumen domba.

\section{DAFTAR PUSTAKA}

AOAC. 1995. Official Methodes of Analysis. Association of Official Analytical Chemist, Washington, DC.

Hermon, Suharyadi, K. G. Wiryawan and S. Hardjosoewignjo. 2008. Nisbah sinkronisasi pasokan n-protein dan energi dalam rumen sebagai basis formulasi ransum ternak ruminansia. Media Peternakan. 31 (3): 187-193.

Pamungkas, D., Y.N. Anggraeni, Kusmartono dan N.H. Krishna. 2008. Produksi Asam Lemak Terbang Dan Amonia Rumen Sapi Bali Pada Imbangan Daun Lamtoro (L. Leucocephala) Dan Pakan Lengkap Yang Berbeda. Seminar Nasional Teknologi Peternakan dan Veteriner 2008. 200-202.

Piao, M. Y., H. J. Kim., J. K. Seo., T. S. Park., J. S. Yon., K. H. Kim dan J. K. Ha. 2012. Effect of synchronization of carbohydrate and protein suply in total mixed ration with Korean rice wine residue on ruminal fermentation, nitrogen metabolism and microbial protein synthesis in Holstein steers. Asian-Aust. J. Anim. Sci. 25 (11): 1571-1573.

Rahmadi, D., Sunarso., J. Achmadi., E. Pangestu., A. Muktiani., M. Christiyanto., Surono dan Surahmanto. 2010. Ruminologi Dasar. Fakultas Peternakan. Universitas Diponegoro, Semarang.

Richardson, J. M., R. G. Wilkinson dan L. A. Sinclair. 2003. Synchrony of nutrient supply to the rumen and dietary energy source and their effects on the growth and metabolism of lambs. J. Anim Sci. 81:1338-1341.

Sani, F. F., L. K. Nuswantara and A. Subrata. 2012. Degradabilitas bahan kering, bahan organik dan neutral detergent fiber limbah industri pertanian dan perkebunan secara in sacco. Animal Agriculture Journal.1 (1):: 747.

Seo, J. K., J. Yang., H. J. Kim., S. D. Upadhaya., W. M. Cho. dan J. K. Ha. 2010. Effect of synchronization of carbohydrate and protein supply on ruminal fermentation, nitrogen metabolism and microbial protein synthesis in Holstein steers. Asian-Aust. J. Anim. Sci. 23 (11): 1455-1457.

Sinclair, I. A, A.P.C. Garnsworthy, J. R. Newbold dan Buttery. 1993. Effect of synchronizing the rate of dietary energy and nitrogen release on rumen fermentation and microbial protein synthesis in sheep. J. Agric. Sci. 120: 251-263.

Steel, R. G. D. And J. H. Torrie. 1981. Principles and Procedures of Statistics. McGraw-Hill Company Inc., New York. 
Wati, N. E., L. K. Nuswantara, F. Wahyono, E. Pangestu dan J. Achmadi. 2015. The Effects Of Synchronization Of Carbohydrate And Protein Supply In Sugarcane Bagasse Based Ration On Body Composition Of Sheep. J. Indonesian Trop. Anim. Agric. 40(4):226-227.

Zamillah, I. F., R. Yulianto., E. Rianto., E. Purbowati and A. Purnomoadi. Kadar hematokrit, glukosa, urea darah dan keluaran kreatinin kerbau akibat frekuensi pemberian konsentrat yang berbeda. Seminar Nasional Teknologi Peternakan dan Veteriner: 142. 